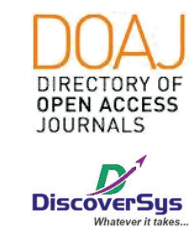

Published by DiscoverSys

\section{Analisis kadar fetuin-A pada pasien dengan sirosis hati di RSUP Haji Adam Malik, Medan, Indonesia}

\author{
Yuni Aflah Lubis, ${ }^{1 *}$ Zulfikar Lubis, ${ }^{1}$ Ilhamd²
}

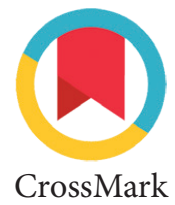

CrossMark

\title{
ABSTRACT
}

Background: Serum Fetuin-A is produced by hepatocytes in adults and its concentration decreases during acute phase reactions in patients with liver disease. Due to it is synthesized in the liver, in some chronic liver diseases the Fetuin A levels decrease as in hepatic cirrhosis. This study aims to determine the difference between Fetuin-A levels in each severity degree in liver cirrhosis patients (Child-Pugh Score). Methods: The study was conducted in the FK USU Clinical Pathology Department / RSUP H. Adam Malik Medan in collaboration with the Gastro Entero Hepatology Division of the Internal Medicine Department FK-USU / RSUP. H. Adam Malik, Medan for the period January to April 2018. An cross-sectional observational analytic method was conducted. There were 33 people with liver cirrhosis and based on Child pugh criteria consisted of 11 cirrhosis patients with liver cirrhosis, 11 class B people, 11 class C people fulfilling the criteria inclusion. The study sample was examined by Fetuin-A and analyzed using SPSS version 17.

Results: There were significant differences in fetuin A levels between groups, namely in class A liver cirrhosis of $273.87 \pm 15.77 \mathrm{pg} / \mathrm{ml}$, class B $247.43 \pm 4.69$ and in class C $191 \pm 10.99$ with a p-value was $<0.000$. In addition, there was a significant difference between the gender with the degree of liver cirrhosis $(P<0.05)$ but not significantly different from the mean age and degrees of liver cirrhosis $(P>0.05)$

Conclusion: There were significant differences in Fetuin-A levels between patients in liver cirrhosis in all three groups based on ChildPugh criteria. However, there was no significant difference in age between the three groups based on Child-Pugh criteria.

Keywords: Cirrhosis, Child-Pugh, Fetuin A.

Cite This Article: Lubis, Y.A., Lubis, Z., Ilhamd, 2019. Analisis kadar fetuin-A pada pasien dengan sirosis hati di RSUP Haji Adam Malik, Medan, Indonesia. Intisari Sains Medis 10(2): 384-387. D0I: 10.15562/ism.v10i2.358

\section{ABSTRAK}

Latar Belakang: Serum Fetuin-A diproduksi oleh hepatosit pada orang dewasa dan konsentrasinya menurun selama reaksi fase akut pada pasien dengan penyakit hati. Karena disintesa pada hati, pada beberapa penyakit hati kronis kadar Fetuin A menurun seperti pada sirosis hepatis. Penelitian ini untuk mengetahui perbedaan antara kadar Fetuin-A pada masing-masing derajat keparahan pada pasien sirosis hati (Skor Child-Pugh).

Metode: Penelitian dilakukan di Departemen PatologiKlinik FK USU/ RSUP H. Adam Malik Medan bekerja sama dengan Divisi Gastro Entero Hepatologi Departemen Penyakit Dalam FK-USU/RSUP. H. Adam Malik,Medan selama periode bulan Januari sampai dengan April 2018.

${ }^{1}$ Patologi Klinik, Fakultas Kedokteran, Universitas Sumatera Utara, Medan, Indonesia 2Departemen IImu Penyakit Dalam, Fakultas Kedokteran, Universitas Sumatera Utara, Medan, Indonesia

*Korespondensi: Yuni Aflah Lubis; Patologi Klinik, Fakultas Kedokteran Universitas Sumatera Utara, Medan, Indonesia, yuni.aflah.ya@gmail.com

Diterima: $13-11-2018$

Disetujui: 17-04-2019

Diterbitkan: 01-08-2019
Penelitian dilakukan dengan metode observasional analitik dengan cara cross sectional Jumlah sampel yang dikumpulkan 33 orang penderita Sirosis Hati dan berdasarkan kriteria Child pugh terdiri dari
Kata kunci: Child-Pugh, Fetuin A, Sirosis, Indonesia. Intisari Sains Medis 10(2): 384-387. D0I: 10.15562/ism.v10i2.358

\section{LATAR BELAKANG}

Fetuin-A adalah glikoprotein yang pertama kali ditemukan pada tahun 1944. Kadar fetuin-A tinggi pada saat fase janin dan berkurang saat fase dewasa, berbanding terbalik dengan Albumin yang penderita Sirosis hati kelas A sebanyak 11 orang, kelas B sebanyak 11 orang, kelas $C$ sebanyak 11 orang orang telah memenuhi kriteria inklusi. Terhadap sampel penelitian dilakukan pemeriksaan Fetuin-A dan dianalisis menggunakan SPSS versi 17.

Hasil: Terdapat perbedaan bermakna kadar fetuin A antar kelompok yakni pada Sirosis hati kelas A sebesar 273,87 $\pm 15,77 \mathrm{pg} / \mathrm{ml}$, kelas B $247,43 \pm 4,69$ dan pada kelas $(191 \pm 10,99$ dengan nilai $p<0,000$. Di samping itu terdapat perbedaan bermakna antara jenis kelamin dengan derajat sirosis hati $(P<0.05)$ namun tidak berbeda bermakna dengan usia rerata antara derajat penyakit sirosis hati $(P>0.05)$

Kesimpulan: Ada perbedaan signifikan Kadar Fetuin-A antara pasien Sirosis hati pada ketiga kelompok berdasarkan kriteria Child-Pugh. Namun, tidak terdapat perbedaan signifikan usia diantara ketiga kelompok berdasarkan kriteria Child-Pugh.

Cite Pasal Ini: Lubis, Y.A., Lubis, Z., Ilhamd, 2019. Analisis kadar fetuin-A pada pasien dengan sirosis hati di RSUP Haji Adam Malik, Medan,

kadarnya lebih tinggi pada saat dewasa. 95\% kadar fetuin Adisekresikan oleh hati sehingga kerusakan sel parenkim hati dapat mempengaruhi kadarnya. Kadar fetuin-A pada pasien dengan penyakit hati 
dapat mencerminkan adanya suatu reaksi fase akut atau kerusakan sel parenkim hati. Fetuin-A merupakan protein fase kut negatif dimana kadarnya turun apabila terjadi infeksi, inflamasi, maupun keganasan, tetapi respon fase akut yang ditimbulkan oleh suatu infeksi yang tidak mempengaruhi fungsi hati seperti demam atau infeksi (sepsis atau pneumonia tidak menurunkan kadar fetuin-a secara nyata. Kadar serum fetuin-a berkorelasi kuat dengan aktivitas prothrombin sebagai indikator terbaik fungsi sintetis dari hati. ${ }^{1}$

Belakangan ini banyak dilaporkan bahwa fetuin A dapat memberikan wawasan baru tentang mekanisme patogen dari berbagai penyakit hati dan kemampuannya dalam mengidentifikasi berbagai penyakit akibat kerusakan sel parenkim hati maka oleh karena itu fetuin-a dapat dijadikan sebagai biomarker untuk penyakit hati. ${ }^{2}$

Sirosis Hepatis merupakan salah satu penyakit hati yang bersifat menahun ditandai dengan adanya pembentukan jaringan ikat disertai nodul. Biasanya dimulai dengan adanya proses peradangan nekrosis sel hati yang luas, pembentukan jaringan ikat dan usaha regenerasi nodul. Distorsi arsitektur hati akan menimbulkan perubahan sirkulasi mikro dan makro menjadi tidak teratur akibat penambahan jaringan ikat dan nodul tersebut.Telah diketahui bahwa penyakit ini merupakan stadium terakhir dari penyakit hati kronis dan terjadinya pengerasan dari hati yang akan menyebabkan penurunan fungsi hati.

Klasifikasi old Child-Turcotte dan berikutnya modifikasi Child-Pugh score (skor CP) telah diaplikasikan secara luas sebagai parameter prognostik pada pasien dengan sirosis dekompensata karena bersifat sederhana untuk digunakan dalam praktek klinis sehari-hari. Determinasi skor CP berkisar antara 5-15 tergantung dari keberadaan dan keparahan asites dan ensefalopati hepatis,pemanjangan waktu prothrombin, kadar bilirubin dan albumin serum. Berdasarkan pada skor CP, pasien diklasifikasikan menjadi tiga kelas (Child kelas A, B, dan C dengan skor $\mathrm{CP}$ masing masing 5-6, 7-9, dan 10-15). ${ }^{3}$

Pasien sirosis dengan HBV (Hepatitis B Virus) kronis, menunjukkan bahwa serum kadar fetuin-A rendah (Dai et al). Kadar fetuin-A menurun signifikan pada sirosis (F4) dan secara signifikan menurun pada fibrosis ringan (F1) berbeda dengan fibrosis (F0). Fetuin-A secara signifikan menurun pada F4 berlawanan F0 dan F1 (korelasi negatif dengan stadium patologis hati). ${ }^{4}$

Korelasi positif kadar serum fetuin-A dengan albumin dapat diinterpretasikan pada sirosis hati karena albumin adalah reaktan fase akut yang negatif yang dianggap sebagai indikator independen dari cadangan sintesis protein hepar (Kalabay et al). Perubahan dalam ekspresi fetuin- A sejalan dengan perkembangan sirosis (kelas Child-Pugh). ${ }^{5}$
Fetuin-A secara signifikan lebih rendah pada pasien dengan sirosis hati dan kanker hepatoselular. Perubahan paling banyak ditandai pada pasien kanker hepatoselular dibandingkan sirosis hati. Ada korelasi negatif signifikan antara kadar serum fetuin-A dengan kriteria Child pugh kelas 3. Korelasi kadar fetuin-A dengan ukuran klinis dan laboratorium sirosis hati dapat dijelaskan sebagai berikut: semakin besar score CP maka semakin rendah kadar fetuin-A maka prognosis penyakitnya semakin buruk. Penelitian ini untuk mengetahui perbedaan antara kadar Fetuin-A pada masing-masing derajat keparahan pada pasien sirosis hati (Skor Child-Pugh).

\section{METODE}

Penelitian dilakukan dengan metode observasional analitik dengan cara cross sectional (potong lintang) artinya penelitian terhadap sampel hanya dilakukan satu kali saja dan tidak dilakukan tindak lanjut. Penelitian ini dilakukan di bulan desember 2017maret 2018 di RSUP H adam malik Medan. Kriteria inklusi dari pasien yang diambil yaitu pasien yang sudah tegak diagnosa sirosis hati dari divisi Gastro Entero hepatologi bagian Ilmu Penyakit Dalam. Sampel diambil dibagian Laboratorium Patologi klinik dan fetuin A diperiksa dengan metode ELISA.

Data penelitian dianalisis menggunakan piranti lunak SPSS versi 17 untuk windows. Data ditampilkan dalam bentuk persentasi, rata-rata dengan simpang baku, maupun dengan nilai P dimana nilai di bawah 0,05 menunjukkan terdapat hasil yang bemakna.

\section{HASIL}

Penelitian dilakukan di Departemen PatologiKlinik FK USU/RSUP H. Adam Malik Medan bekerjasama dengan Divisi Gastro Entero Hepatologi Departemen Penyakit Dalam FK-USU/RSUP. H. Adam Malik,Medan selama periode bulan Januari sampai dengan April 2018.

Jumlah sampel yang dikumpulkan berdasarkan uji statistik sebanyak 33 orang penderita Sirosis Hati dan berdasarkan kriteria Child pugh terdiri dari penderita Sirosis hati kelas A sebanyak 11 orang, kelas B sebanyak 11 orang, kelas C sebanyak 11 orang orang telah memenuhi kriteria inklusi. Terhadap sampel penelitian dilakukan pemeriksaan Fetuin-A. Data yang dikumpulkan disajikan dalam bentuk tabel.

Pada tabel 1 menunjukkan karakteristik subjek penelitian berupa jenis kelamin dan umur. Pada penelitian ini Sirosis Hati kelas A berjumlah 11 orang yang terdiri dari 10 orang laki-laki dan 1 orang perempuan dengan rerata umur 47,27 $\pm 3,05$ tahun, Sirosis Hati kelas B berjumlah 11 orang yaitu 9 orang 
Tabel 1 Karakteristik dasar subjek penelitian

\begin{tabular}{lcccc}
\hline & \multicolumn{3}{c}{ Sirosis Hati } & \multirow{2}{*}{ Nilai $\boldsymbol{p}$} \\
\cline { 2 - 3 } Karakteristik & Kelas A $(\mathbf{n}=\mathbf{1 1})$ & Kelas B $(\mathbf{n}=\mathbf{1 1})$ & Kelas C $(\mathbf{n}=\mathbf{1 1})$ & \\
\hline Jenis Kelamin & & & \\
Laki-laki & $10(90,91 \%)$ & $9(81,82 \%)$ & $11(100 \%)$ & $0,001^{\text {a }}$ \\
Perempuan & $1(9,09 \%)$ & $2(18,18 \%)$ & $0(0,0 \%)$ & $0,688^{\text {b }}$ \\
Umur $($ Mean \pm SD) & $47,27 \pm 3.05$ & $52,09 \pm 3.75$ & $50,27 \pm 2.39$ & \\
\hline
\end{tabular}

${ }^{a}$ Chi-square

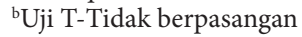

Tabel 2 Kadar Fetuin-A pada Sirosis Hati berdasarkan kriteria Child -Pugh (CP)

\begin{tabular}{lcccc}
\hline & \multicolumn{3}{c}{ Sirosis Hati } & Nilai $\boldsymbol{p}$ \\
\cline { 2 - 4 } Karakteristik & Kelas A $(\mathbf{n}=\mathbf{1 1})$ & Kelas B $(\mathbf{n}=\mathbf{1 1})$ & Kelas C $(\mathbf{n}=\mathbf{1 1})$ & \multirow{2}{*}{$0,001^{*}$} \\
\hline Fetuin-A $(\mathrm{pg} / \mathrm{mL})$ & $273,87 \pm 15,77$ & $247,43 \pm 4,69$ & $191,11 \pm 10,99$ & 0 \\
\hline
\end{tabular}

*Uji T-Tidak Berpasangan; Nilai P dikatakan bermakna apabila kurang dari 0,05

laki-laki dan 2 orang perempuan dengan rerata umur

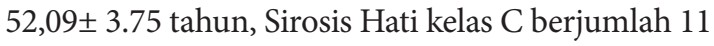
orang yaitu 11 orang laki-laki dan tidak ada pasien perempuan dengan rerata umur 50,27 \pm 2.39 tahun. Tidak terdapat perbedaan secara signifikan antara usia pada ketiga kelompok berdasarkan kriteria Child Pugh dengan nilai $p=0,688$. Namun terdapat perbedaan yang signifikan pada jenis kelamin pada ketiga kelompok tersebut dengan nilai $p=0,001$.

Hasil uji normalitas menunjukkan bahwa data kadar Fetuin pada kelompok Sirosis hati berdasarkan kriteria Child pugh dengan nilai $P=0,083$ $(\mathrm{P}>0,05)$. Nilai ini menunjukkan bahwa kedua data tersebut berdistribusi normal sehingga selanjutnya dapat dilakukan uji beda dengan menggunakanUji ANOVA maka dilakukan uji post hoc untuk mencaari perbedaan kadar fetuin yang paling tinggi (dengan mengujinya secara berpasangan)

Berdasarkan Uji T-tidak berpasangan dapat disimpulkan bahwa terdapat perbedaan Kadar Fetuin-A yang signifikan pada pasien Sirosis hati pada ketiga kelompok berdasarkan kriteria $\mathrm{CP}$ dengan $P=0,001$ $(\mathrm{P}<0,05)$. Fetuin-A adalah suatu glikoprotein yang disintesa oleh hati (sekitar 95\%) dan pada masa embrio fetuin A ekspresikan oleh beberapa jaringan.

\section{PEMBAHASAN}

Karena disintesa pada hati, pada beberapa penyakit hati kronis kadar Fetuin A menurun. Dari berbagai laporan Fetuin A kadarnya berkurang pada penyakit hati dan telah terbukti sebagai faktor independen pada mortalitas jangka pendek pada sirosis hati. ${ }^{7} \mathrm{Hal}$ ini kemungkinan karena semakin berat sirosis hati, semakin berkurang massa sel hati akibat banyaknya fibrosis. Sehingga fetuin A yang dihasilkan semakin sedikit. Penurunan seperti ini juga ditemukan pada penyakit hati kronis seperti sirosis hati, biliari sirosis primer, hepatitis kronis dan kanker hati mengingat sintesa fetuin A berlangsung di hati. ${ }^{7}$

Pada penyakit hati kronis tersebut juga nilai dari fetuin A menurun, hal ini juga mencerminkan terjadiny degradasi hepatosit sehingga massa hepatosit menurun, yang menyebabkan sintesa fetuin A menurun. Penurunan tersebut sejalan dengan semakin beratnya tahapan dari sirosis hati. Dimana kelas $C$ lebih rendah disbanding kelas $B$ dan kelas B lebih rendah dari kelas A. penelitian lain menyebutkan sesuai yang ditemukan di penelitian ini dimana kelas C lebih buruk dari kelas B dan A. ${ }^{6}$

Fetuin A merupakan suatu tes yang baru, penelitian lain mencoba mengaitkan antara nilai fetuin A yang rendah dengan resiko kematian. Peneliti menggunakan kurva ROC mendapatkan nilai cut off $365 \mu \mathrm{g} / \mathrm{ml}$. berdasarkan cut off tersebut banyak pasien yang kadar fetuin $\mathrm{A}<365 \mu \mathrm{g} / \mathrm{ml}$ meninggal setelah 1 tahun follow up. Oleh karena itu, Fetuin A ini juga dapat digunakan sebagai marker prognosis untuk penyakit sirosis hati. ${ }^{8}$

Selain untuk menilai kerusakan hepatosit Fetuin A juga berperan sebagai biomarker kardiovaskular. Pada pasien dengan dengan PJK (Penyakit Jantung Koroner) nilai fetuin A menurun. Sehingga apabila menemukan nilai fetuin A yang rendah seorang pasien harus diwaspadai ada kerusakan hepatosit dan proses fibrosis vascular. ${ }^{9}$

Dari 33 pasien sirosis hati pada penelitian ini ditemukan 20 seromarker HbsAg (+), dan tidak ditemukan seromarker anti $\mathrm{HCV}$ pada pasien penelitian ini. Belum jelas penyebab sirosis hati pada pasien-pasien dengan seromarker $\mathrm{HbsAg}$ (+) dan anti HCV (-). Mungkin keadaan-keadaan lain yang menyebabkan sirosis hati seperti alcohol, obat-obatan..$^{10}$

Tingginya penyebab sirosis hati oleh virus hepatitis B 60,6\% pada penelitian ini juga tercermin pada 
penelitian-penelitian penyebab sirosis hati oleh virus hepatitis B di kawasan Asia Tenggara yang relatif tinggi. Prevalensi sirosis hati di Indonesia belum diketahui secara pasti, hanya berdasarkan pada penelitian-penelitian yang dilakukan di Rumah Sakit Umum Pemerintah.

Menurut penelitian Nur Rahmah pada periode janurai 2011 - juni 2013, diperoleh hasil penelitian : dari 100 sampel yang diteliti, berdasarkan kelompok umur menunjukkan bahwa insiden sirosis hati terbanyak terjadi pada rentang umur 40-49 tahyn dengan jumlah kasus 43 orang (43\%), jenis kelamin terbanyak adalah laki-laki sebanyak 79 (79\%), dan 35 orang $(35 \%)$ mengatakan pernah menderita hepatitis B sebelumnya. ${ }^{11}$

Penelitian Herlida tahun 2015, dari 87 penderita sirosis hati didapatkan 61 penderita $(70,11)$ berjenis kelamin laki-laki dan 26 orang $(29,89 \%)$ penderita berjenis kelamin perempuan. Bila dihitung perbandingan antra laki-laki dan perempuan, maka rasionya 2,4:1. Dari sampel yang diteliti ditemukan sirosis hati yang terkait virus hepatitis B dengan seromarker hepatitis B surface antigen (HBsAg) positif sebanyak 31 kasus. Menurut Karina (2007), laki-laki menderita sirosis hati kemungkinan karena laki-laki adalah kepala rumah tangga yang harus bekerjs keras tanpa memperhatikan kemampuan fisik dan mentalny sehingga lebih mudah terkena penyakit, khususnya berbagai penyakit infeksi (Hepatitis B). ${ }^{12}$

Pada penelitian ini ditemukan 90,9\% laki-laki dan 9,1\% perempuan. Tingginya frekuensi pria pada pasien sirosis hati pada penelitian ini kemungkinan karena aktifitas fisik kaum laki-laki lebih banyak diluar rumah sehingga lebih mudah tereksposur oleh virus hepatitis B yang didalam perjalanannya menjadi sirosis hati.

\section{SIMPULAN}

Ada perbedaan signifikan Kadar Fetuin-A antara pasien Sirosis hati pada ketiga kelompok berdasarkan kriteria Child-Pugh . Tidak ada perbedaan signifikan usia diantara ketiga kelompok berdasarkan kriteria Child-Pugh. Tidak ada perbedaan yang signifikan usia diantaraketiga kelompok berdasarkan kriteria childpugh. Namun terdapat perbedaan yang signifikan pada jenis kelaminpada ketiga kelompok tersebut.

\section{KONFLIK KEPENTINGAN}

Penulis menyatakan tidak terdapat konflik kepentingan dalam penulisan laporan hasil penelitian.

\section{ETIKA PENELITIAN}

Penelitian ini telah memperoleh persetujuan etik dari komisi etik akultas Kedokteran, Universitas Sumatera Utara, Medan, Indonesia.

\section{PENDANAAN}

Studi ini dilakukan menggunakan pendanaan dari penulis sendiri tanpa keterlibatan pendanaan dari pihak sponsor atau hibah penelitian.

\section{KONTRIBUSI PENULIS}

Seluruh penulis berkontribusi dalam penyusunan laporan akhir penelitian dari tahap penyusunan usulan proposal, analisis data, hingga penyampaian laporan akhir penelitian.

\section{DAFTAR PUSTAKA}

1. Kalabay L, Gráf L, Vörös K, Jakab L, Benko Z, Telegdy L et al. Human serum fetuin A/ $22 \mathrm{HS}$-glycoprotein level is associated with long-term survival in patients with alcoholic liver cirrhosis, comparison with the Child-Pugh and MELD scores. BMC Gastroenterol. 2007; 7: 15.

2. Vörös K, Cseh K, Kalabay L. The role of fetuin-A in cardiovascular diseases. Orv Hetil. 2014; 155(1):16-23

3. Lebreton JP, Joisel F, Raoult JP, Lannuzel B, Rogez JP, Humbert G. Serum concentration of human alpha 2 HS glycoprotein during the inflammatory process: evidence that alpha $2 \mathrm{HS}$ glycoproteinis a negative acute-phase reactant. J Clin Invest. 1979; 64(4):1118-29.

4. Dai XH, Zhang P, Xiao MF, Zhou RR, Zhang BX, Hu GS, et al. Protective role of a2HS-glycoprotein in HBVassociated liver failure. Int J Mol Sci. 2011; 12(6):3846-56.

5. Prystupa A, Dąbrowska A, Sak JJ, Tarach J, ToruńJurkowska A, Lachowska-Kotowska P. Concentrations of fetuin-A, osteoprotegerin and a-Klotho in patients with alcoholic liver cirrhosis. Exp Ther Med. 2016; 12(5):3464-3470

6. Mohamed SY, El-darawy MM, Salama NA, Mansour SA. Serum Fetuin A level in patient with chronic liver disease and hepatocellular carcinoma . International Journal of Advanced Research. 2015; 3(5):476-477.

7. Dabrowska AM, Tarach JS, Wojtysiak-Duma B, Duma D. Fetuin A (AHSG) and its usefull in clinical practice. Review of the literature. Biomed Pap Med Fac Univ Palacky Olomouc Czech Repub. 2015; 159(3):352-9.

8. Vörös K, Prohászka Z, Kaszás E, Alliquander A, Terebesy A, Horváth F. Serum ghrelin level and TNF- $\alpha$ /ghrelin ratio in patients with previous myocardial infarction. Arch Med Res. 2012; 43(7):548-54.

9. Sato M, Kamada Y, Takeda Y, Kida S, Ohara Y, Fujii H, et al. Fetuin-A negatively correlates with liver and vascular fibrosis in nonalcoholic fatty liver disease subjects. Liver Int. 2015; 35(3):925-35.

10. Burrough AK, Dooley JS, Lok ASF. Sherlock's Diseases of the Liver and biliary system. $12^{\text {th }}$ edition. Uk: Blackwell Publishing Ltd. 2011.

11. Rahmah N. Karakteristik Penderita Sirosis Hati yang dirawat inap di RSUP dr. Wahidin Sudirohusodo Makassar periode Januari 2011- Juni 2013 [Skripsi]. 2013.

12. Herlida, Mulyadi Y, Novianny V. Hubungan skor Apri (Aspartat Aminotransferase to Platelet Ratio Index) dengan derajat keparahan sirosis hati di RSUD Dr. Soedarso Pontianak. Jurnal Mahasiswa PSPD FK Universitas Tanjungpura. 2015;3(1)1-21.

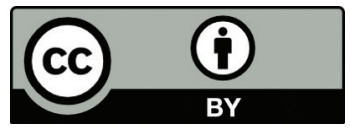

This work is licensed under a Creative Commons Attribution 